Rules which pay are going to stay: Indigenous institutions, sustainable resource use and land tenure among the Ouldeme and Platha, Mandara Mountains, Northern Cameroon

\title{
Tobias Haller
}

\section{OpenEdition}

Journals

Édition électronique

URL : http://journals.openedition.org/apad/148

DOI : $10.4000 /$ apad. 148

ISSN : $1950-6929$

Éditeur

LIT Verlag

Édition imprimée

Date de publication : 1 décembre 2001

Référence électronique

Tobias Haller, « Rules which pay are going to stay: Indigenous institutions, sustainable resource use and land tenure among the Ouldeme and Platha, Mandara Mountains, Northern Cameroon », Bulletin de l'APAD [En ligne], 22 | 2001, mis en ligne le 20 février 2006, consulté le 08 septembre 2020. URL: http://journals.openedition.org/apad/148 ; DOI : https://doi.org/10.4000/apad.148

Ce document a été généré automatiquement le 8 septembre 2020.

Bulletin de l'APAD 


\title{
Rules which pay are going to stay: Indigenous institutions, sustainable resource use and land tenure among the Ouldeme and Platha, Mandara Mountains, Northern Cameroon ${ }^{1}$
}

\author{
Tobias Haller
}

Introduction :

Much has been written in what respect and why Africa does not show good governance. Some of these studies focusing on the state as the "Black Man's Burden" (Davidson B., 1992), others are pointing at the weak formal institutional aspects, corruption and the "Politics of the Belly" (Bayart J.F., 1993). More challenging and interesting are nevertheless analysis which argue that "Africa works", showing how Africa is governed for example by patron-client-systems. This is not only done by Chabal and Daloz (1999), but as well by others, who are interested in the question of governance and natural resource use (see for example Gibson C., 1999). What is lacking however is an analysis which does not only look at formal institutional aspects (which are missing or not well established) but which takes up some of the interesting theoretical framework of the New Institutionalism (North D., 1990, Ensminger J., 1992, 1998, Ostrom E., 1990, Becker D. C., and Ostrom E., 1995). In spite of these approaches not being so new anymore and focusing on economic theories, much insight is to be gained from them when discussing public services governing natural resource use. What is especially interesting in these approaches is the focus on so called informal institutions (rules, values, norms, constraints and customary laws), which have been developed by local groups in order to regulate for example resources held in private (land) or in common property (pastures, fisheries, etc.). In absence of the effective working of formal institutions, older informal, indigenous rules or transformed versions of these "rules of the game", give local people a framework for action. The article will illustrate by using the example of the Ouldeme and Platha, two peasants groups in the Mandara 
Mountains, Northern Cameroon (Haller T., 1999, 2000, 2001) how local indigenous institutions have worked in former times and how they work now ${ }^{2}$. It is argued that they are being transformed by a wider national and international economic system and natural environmental changes (climatic change) as well as by the interplay with formal institutions. It would be wrong to say that formal rules (such as formal land law or fishery rights) are not operating at all. They are always a strategic possibility for actors in order to gain access to resources in a specific process (see for example the work of Christian Lund (1998)). The article argues that the kind of institutions being applied to use natural resources (be it formal or informal) depend on specific situations, in which strategic bargaining power of different actors -local as well as strangers and administrators- is important. Additionally, it is argued that the operation and the design of the transformed indigenous institutions are determined whether they give easy access to financial revenues (especially cash). The hypothesis being discussed here says that indigenous institutions, which would actually be beneficial for sustainable resource use but do not give access to cash, are transformed or eradicated, while those local institutions, which stay in place, are mostly being transformed for cash-gaining purposes. This transformation is important because in the discussion over public services governing natural resources, the question of local participation and incorporation of indigenous rules are crucial.

New Institutionalism and its role in analysing resource use

What is new about the New Institutionalism and how is it able to contribute to the discussion of sustainable resource use, indigenous institutions and governance? Different approaches can be subsumed under this label, where institutions are seen as formal and informal "rules of the game", such as constraints, norms, values and rules. These give incentives for groups and individuals, and also structure human action and interaction, especially in economic activities, in collective action and in sustainable resource use. Institutions such as property rights systems or laws are developed by the state (often called "formal" institutions in written form) or by local communities where they are embedded in their culture (so called "informal" institutions based on orally transmitted custom) (North D., 1990, Ostrom E., 1990, Ensminger 1992, 1998)³. An important aspect of explaining how institutions operate is illustrated by the work of economists such as Douglass North (1990). He not only states that institutions matter for economic activities (Old Institutionalism) but that if institutions work properly they reduce what in economics is called transaction costs. These are the costs that arise when two people engage in an economic transaction, which is, as Ronald Coase has shown, costly. To make a transaction one has to have information about product quality and about the other actors' behaviour. One also has to monitor the other actors and sanction them when needed. All these activities are costly because they consume time and resources (North D., 1990). The interesting thing about looking at this theory in analysing the management of natural resources is the fact that it raises questions about some long held theories. In the debate on common property resources (CPR) and sustainability for example, the notion of Garret Hardins famous "Tragedy of the Commons" paradigm (Hardin G., 1968) ${ }^{4}$ could actually be undermined by a close look at how CPR-institutions work. Elinor Ostrom's work illustrates this by analysing different CPR institutions and their management by local communities all over the world. By looking at successfully operating, locally developed institutions that showed sustainable use of natural resources such as forests, irrigation water, fisheries, pastures, eight 'design principles' for effective operating institutions were developed. 
These include, among others, the clear drawing of boundaries of resource territories and it's users, collective choice arrangements, monitoring, sanctioning and conflictresolution mechanisms. So most of them can actually be included in the notion of transaction costs. If institutions operate properly they in fact reduce these costs. The same aspect we have with the notion of private property rights or state property regimes, which were proposed by Hardin and neo-classical economists to solve the "Tragedy of the Commons" - if, and only if the lowering of the transaction costs work. If they do not work because these formalised institutions are badly governed, they in fact rise transaction costs as is shown in the work of exponents of the New Institutionalism (Ensminger J., 1997, Ostrom E.,1990 and Acheson J., 1989).

3 When we have a look at traditional resource use systems and institutions and we see actual cases of unsustainable resource use, we should spend more time in looking at the history of an area. Additionally, we should focus on how informal institutions have changed and how formal state institutions intervene or not with local rules of the game. The destruction of these resources (held in private property) and the changes in local institutions will be focused on in an example from northern Cameroon. The theoretical background is the New Institutional Economic Anthropology (Ensminger J., 1992) which analyses changes in institutions caused by shifts in so-called relative prices. By this term Ensminger means external influenced changes of prices for goods in relation to other goods (for example rise in cattle or fish prices compared to other goods). But as well, on a bigger scale, I would incorporate in this notion changes in the political and economic environment (pacification, new urban centres and new markets, monetarisation), in state control (laws, police, administrators), in infrastructure and transport systems (lowering costs for marketing or access by other groups) etc.). As a result of these changes, endogenous factors in a local society, such as institutions, organisations, ideology and bargaining power are altered. Institutional changes and changes in bargaining power will be especially focused on. Ensminger has shown, that those actors in a society whose economic situation has been strengthened by the change in relative prices are becoming more powerful, and have more so-called 'bargaining power' to transform, erase, or replace institutions with new ones. In line with Douglass North, she illustrates that it is not the institutions which give the best result for all people involved that are selected, but the institutions that serve those actors with the most bargaining power (Ensminger J., 1992, North D., 1990).

4 The hypothesis I would like to present for discussion is that locally developed institutions who were working in former times do not work anymore. They are altered by the powerful and because the monetarising process (a strong change in relative prices) changed the institutional setting in a specific way as well. Those traditional institutions, that can be monetarized will stay in place, while those who are in the way or hinder the adaptation of the local users to earn cash with these resources - cash which is needed not only for consumer goods of the globalized world but as well for the building up of social networks (marriage etc., see also Berry S., 1989, 1993) - will be selected against. I would like to illustrate this hypothesis by using the example from my own fieldwork in the Mandara Mountains in Northern Cameroon.

Traditional institutions for a sustainable land use among the Ouldeme and Paltha ${ }^{5}$

5 The Ouldeme and the Platha are two traditional farming communities with a total of 6700 people who live in an area of $34 \mathrm{~km}^{2}$ belonging to the north-eastern part of the Mandara mountains adjacent to plain areas in northern Cameroon. In pre-colonial 
times, they have turned their territory into an impressive cultural landscape covered with terraces and tree parks as many of the so-called Kirdi-groups in the area did. With $191 \mathrm{p} / \mathrm{km}^{2}$ the territory is densely populated seen the sandy soils and the semi-arid climate. This high population density without exceeding the carrying capacity of the territory was made possible with a very intensive traditional agricultural system, making use of terraces, trees, manure and an intercropping techniques. Important in this system is the constant repair of the terraces, which takes between one fifth or one fourth of the whole production time on a field. This "agricultural intensification" (an increase in productivity with a lower working productivity; see Boserup E., 1965) has its roots in the natural and political environment. To the former - an ecosystem with highly and chaotic variations in rainfall during the short rainy season - the Ouldeme and Platha adapted by developing a inter-cropping system and sorghum storing techniques which secured nutrition of the people even in times of bad harvest. The later consisted in slave-hunting groups in the plains such as especially the Islamic Mandara and Fulbe as well as their animistic neighbours called Mada. The mountain area of the Ouldeme and Platha became a refuge in which the people had to use the land intensively without any fallow period for there was no possibility of moving away. Additionally, there were institutional guidelines for the use of the soil and a wise management of the harvest, which contributed to a sustainable use. But as can be shown from my data (Haller T., 1999, 2000, 2001), it is not so easy to return to traditional institutions for the sustainable use of natural resources nowadays, because they have been altered after many changes in relative prices during colonial and postcolonial times until now. These institutions have become suboptimal for economically rational individual actors under the new circumstances of pacification, market incorporation, monetarisation and climatic change. And this despite the fact that they provided a positive answer to pressing environmental and resource use problems in the past and still would provide an answer today. The institutions I would like to discuss here are the prohibition of selling sorghum, reduction of beer production and forced repair of terraces.

6 Among the Ouldeme and Platha, the sale of the staple crop sorghum was not allowed in former times. To do so, the people believed would provoke the anger of different spirits and the soul of the plant sorghum. This would then lead to supernatural sanctions with the consequence of bad harvests and the "leaving of the grains" from the threshing grounds and granaries. This institution served well to promote a wise management of excess sorghum in times of good harvest and also reflected the refugium situation in which the Ouldeme and Platha found themselves. As they were so dependent from this crop, the worship of its soul and the presence of surrounding spirits affecting its performance was no surprise. I would not argue here, that religion is functional in this way (meaning that religion is there because it is managing the harvest wisely). But I would argue that the animistic religion -being certainly older than the prohibition to sell sorghum - served well in order to be used as a monitoring and sanctioning device in times when markets started to develop in the plain areas, which were nevertheless not save yet. So this institution was lowering transaction costs for storing sorghum for hungry times while rising the costs for selling the staple crop in an unwise manner for short term needs with negative long term consequences. Religion served here well because in times when cash was not important in economic and social life this was not an obstacle for the household economy but helped to manage the harvest wisely. The interesting thing about this taboo to sell sorghum is that the rule was not questioned 
and submission to it was embedded in an already existing believe of how souls and spirits act in an animistic world. Believing in this ideology or worldview made it easier to sell other goods, when the markets were opening up even in colonial and the first part of the post-colonial times, and not touch the staple crop so vital for people's survival.

7 Another institutional aspect regarded the restricted production of sorghum beer. This beverage is very important for the Ouldeme and Platha for it is used in many crucial religious and economic situations during the agricultural cycle. It is one of the modes of payment in co-operative work for example for threshing sorghum, for house building (roof work), acquiring of additional working forces in for weeding fields or repairing terraces etc. Important is the beer production for marriages during which the female relatives on side of the groom brew beer for the side of the bride. But most importantly, beer is needed for religious festivals and for rituals, during which local spirits are feed with beer and meat. In spite of beer being such a valuable beverage there were institutionalised limits for its production. Only old men were allowed to drink, the younger men and the women were excluded or had only limited access to beer. This can be seen as unjust but it had the consequence to limit the beer production. At the same time beer was not produced for sale. To produce beer, the women were only allowed for the occasions mentioned above. Interesting in this respect is the fact that by this way the use of firewood was limited. Because the Ouldeme and Platha women cook with the stalks of the major plant sorghum, beer production was the only activity where fuel wood was needed (apart from wood for iron production but which was quite small during the year). By this way beer production was ruled in former times which as well served well for the wise management of the harvest and to prevent the unwise use of the staple crop that was needed in times of bad harvests. It is clear that this animistic religion of the Ouldeme and the Platha do not have any thing in common with a protestant kind of uneasyness for festivals and as in any indigenous farmer and peasant society festivals and rituals are important for several reason. But seen the difficult political situation these people were in, the institution governing the production of beer ensured that the party goes on from time to time but under special circumstances only. In this way regulated and embedded in the animistic believe system, it prevented the excessive use of the harvest. Again here transaction cost reduction is the positive side of the institution. For the wise long term use of the harvest and the prevention of excesses, it provided information, monitoring and as well sanctioning in a face to face community.

8 A third important institutional aspect regards land title issues and maintenance work of terraced fields: In former times there were rules for repairing terraces. The land tenure system is based on two major kinds of ownership and user rights in the system of private property. Because there is much work invested in the terraced fields, they are owned privately by the head of the household as predicted by Boserup's theory on intensification and land rights (Boserup E., 1965) and inherited by all sons in equal shares. Because this leads to fragmentation of fields into small parcels there is the possibility of selling and buying land (with the use of special purpose money). But there were rules regarding the sale: First one had to look for a buyer within the lineage or clan in the own mountain area section before a field could be sold to an outsider of another section. There was in the case of need of special purpose money (used as well for paying the bride price) the possibility to mortgage a field. The usufruct rights over a field was given until the owner would return the sum given to him by the user of the 
field. These land use rules enabled the households with different demographic dynamics to regulate the different land requirements due to the changing size of their households. Following the theory of Alexander Chayanov, the Ouldeme and Platha serve as an example to illustrate his theory of the consumer-worker-balance. Although the Ouldeme and Platha do not have land abundance as in the example Chayanov uses with his Russian material, one can see that larger households with a larger unbalance of the consumer-worker ratio (more consumers as workers and as well bigger households) had to cultivate more land and work more because they needed this for their subsistence. So the rules for selling and mortgaging were used in order for the bigger households at a specific time in their family life cycle to get access to more land. A crucial aspect in the land tenure system was the maintenance work: Privately owned fields, as well as mortgaged fields, needed to be constantly repaired because an eroded field would eventually cause severe soil erosion for the whole territory. The user of a mortgaged field - who had given some amount of traditional money to the owner in order to get the right to use the field until he gets the money back - lost his field if he did not repair the terraces on a regular basis. If an owner himself neglected repairing their terraces, the community could sanction him for example with no co-operation in times of need (co-operative work such as threshing etc.) or exclusion on rituals and other social activities. So here as well the institutional rules reduced the transaction costs for the secure transfer of land use rights and of soil maintenance in the whole region as they provided information, monitoring and sanctioning at low costs.

In a transformed form of the original Chayanov model, the individual incentives to stay in the mountain area and to maintain the institutions presented here can be shown in a graph in which I have introduced not only the utility and drudgery functions of additional work and cultivated land (as used by Chayanov) but the political environment outside the mountain area as well. Note that this graph is used in order to illustrate the utility or disutility seen the pre-colonial circumstances as reported to me by old people and not to give exact calculations which is of course not possible. 
Graph 1: Pre-colonial environmental adaptation of the Ouldeme and Platha based on the changed model of Chayanov

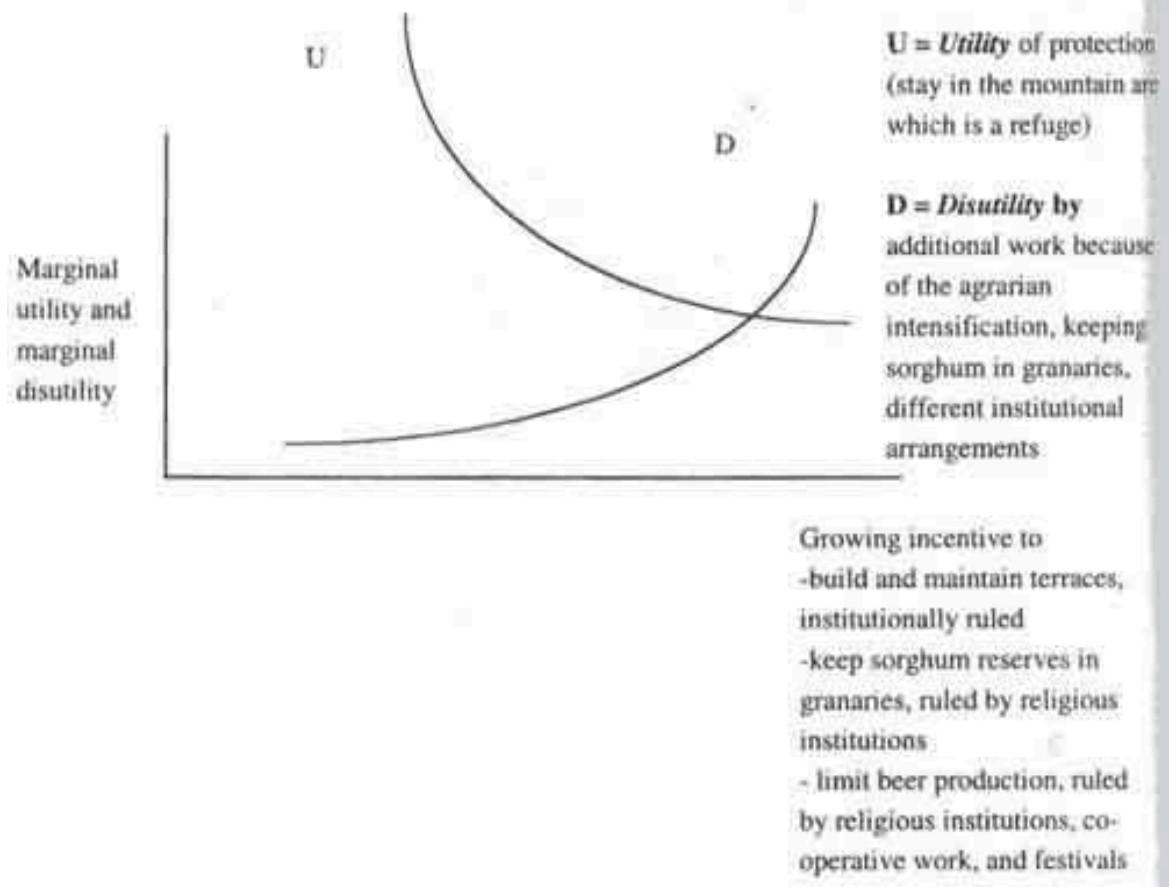

Food crises and soil erosion trough institutional change

There have been major changes in these institutions since the pre-colonial time. The most important being the pacification in the plain areas, abolition of slavery and the introduction of cash for tax payment by the French and the post-colonial government as well as climatic changes in the 1980ties. As I will show in my paper these changes are leading to major transformations in the three institutional settings presented above. The institutionalised rules discussed above no longer operate because the strategies which were acted against in former times - selling sorghum, producing sorghum beer on a commercial basis and neglect of terrace repair - have now become very important for gaining cash. Cash is one of the most important resources in a monetarised sociopolitical environment, where marriage, kinship and other social networks are based on monetary obligations nowadays. The tension to gain cash is extremely high among Ouldeme and Platha especially after climatic changes made growing cash crops such as cotton and ground nuts unprofitable. The consequences of these strategies - and the abolishment of the old institutional rules - is that the granaries are often empty before the end of the rainy season. Additionally, there are no longer any reserves in times of famine (due to disasters such as rainfall, plagues of crickets and caterpillars etc.) with very obvious negative consequences. The reason for this is that the old sorghum selling taboo cannot be maintained anymore. As there is no income from the cash crops anymore one substitution strategy is to sell sorghum even if people know that by this they jeopardise the wise management of their harvests. Unfortunately most of the staple crop is sold before a major religious festivals where monetary obligations for the heads of the households are very high (gifts for children, relatives and wives). This leads then to very low sorghum prices for everybody is selling at the same time. Islamic traders with their lorries from the nearby cities of Mora and Maroua profit from the 
low price. They buy sorghum in high quantities, store it in the cities and wait until the price has reached three or four times the initial price. Sometimes the same sorghum is sold again back to the same farmer.

11 The second institution, which is abolished, is the rule that sorghum beer is not produced commercially. As there is no money from the cash crops anymore, from which the women were given some amount from the men in previous times, producing and selling beer is the only possible cash substitution. Therefore beer production has more than doubled in the last 6 to 10 years since my research in the 1990/1ties. This production has led to poor allocation of scarce sorghum and to abusive logging in the area for firewood, needed for the commercial beer production.

Another institutional change can be seen in the forced maintenance of terraced fields, were the old institutions do not work anymore. Today, there are major changes taking place regarding the land tenure system and the regulation of the land maintenance:

- The users of mortgaged fields are no longer willing to do maintenance work. Good maintenance improves soil quality and the value of a field and, therefore nowadays, the price in cash that can be obtained by the owner. He will then take away the well repaired field form the actual user and give it to a peasant, who pays him more money than the old mortgaging user. In order to prevent this, terraces in mortgaged fields are not repaired anymore by the actual users.

- Additionally, there is now a new main form of tenure, where the land is rented on a yearly basis. This also leads to the neglect of terraces because the time horizon is too short for the user to invest more work in a field, which he will probably not use in the following year.

- It is as well very interesting to see that sometimes not only the rented and mortgaged fields show erosion but as well the fields used by an owner himself. This can be due to the fact that the owner has lost his working forces (especially sons) and was not able to repair the terraced fields properly. Sons will leave their fathers today if they are not able to contribute cash to the bride price. Pacification, free mobility, and market opportunities in the cities makes migration a viable option in order to obtain cash.

13 So changes in relative prices - especially pacification and free mobility after the abolition of slavery, monetarisation through tax payment, cash crop production, climate change and shift from former cash crops to the sale of sorghum - changed the local bargaining power of young men and the women compared to the heads of the household. This leads to institutional changes as the consequence of the adaptation by the individual actors to the monetarized world. In conclusion, this can be summarised as follows: The three traditional institutions (prohibition of sorghum sales, restricted production of beer, and maintenance of terraces) which still make sense today, are no longer useful for the individuals in a monetarised world, because they make it difficult to obtain cash. When discussing why these institutions were working in former times but not today anymore with local people, they were very clear about the cause: The need to have cash at hand is of major importance for social survival, something the German Anthropologist Georg Elwert has called "venality" ("Venalität" or Käuflichkeit of social relation ships, see Elwert G., 1985, 1989). All the discussions regarding social relationships during the time of my fieldwork were focussing on money. Without cash one could not exist socially for the social networks were totally monetarised. The major changes and utility/disutility functions can as well be qualitatively shown in graph 2 (by using graph 1 and adapting it to the changes): 
Graph 2: Changes in relative prices and environmental adaptation among the Ouldeme und Platha between 1890 und 1990 based on the new Chayanov-Model

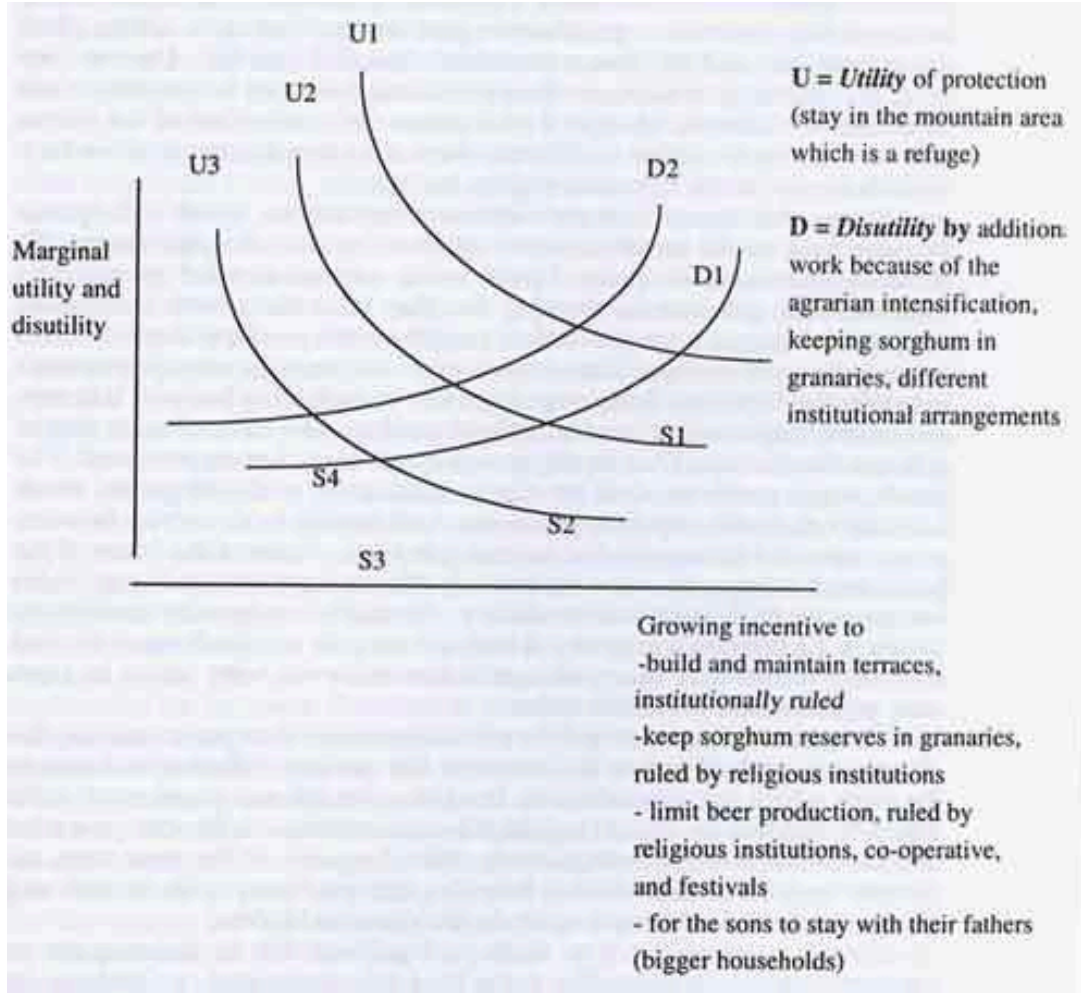

U1: pre-colonial time, U2: colonial time, U3 first post-colonial time (1960 to 1980)

D1: marginal disutility between pre-colonial time and 1980, D2: marginal disutility after 1980 (climatic change)

S: Intersections which show on the $x$-axis how big or low the incentive is to keep the institutions discussed.

The graph can be interpreted as follows regarding to the different incentives in the different times: U1 shows a high utility to stay in the mountain area and to develop and maintain the three institutions discussed for it made sense in a situation of high hostility and slave raids. This utility is constantly lowered as pacification and monetarisation is taking place during colonial and the first pre-colonial time (U2 and U3). On the other hand the disutility to maintain the institutions discussed is low before and high after the climatic change. S1-S4 shows the intersection of the curves that indicate the incentive to maintain the institutions that are positive for a sustainable use of the resources and the harvest.

On the other hand, there are traditional institutions, which still operate because they could be monetarised and can be used to gain money. To those belong the bride price. I have made comparisons for pride prices between three generations showing that they have risen from some goats and special purpose money which people could produce themselves in times before and during colonial times up to six times an average peasant's salary in the 1990ties. Bride price has risen considerably because it is now one of the major ways for a household head to gain cash. The buying of gifts for the bride and her family is nowadays very important as well. The goods, which are demanded, are mostly industrially produced goods, which can only be obtained by cash payments. Additionally bride service between young men of a lineage or clan for example on the fields of the father of the future bride cannot be made by making reference on 
reciprocity anymore but most be paid in cash immediately. Generally, reciprocity institutions inside a lineage or kin-group which all stay in a transformed version including massive monetary obligations, where everybody seems to know how much another owes him or her.

There are various external formal institutional changes worsening the situation as well: The state in Cameroon has outlined different land laws in the past, which are contradictive, favouring the Islamic population in the plains surrounding the Mandara Mountains (especially the powerful traditional Fulbe and Mandara-chiefs called Lamido). At the same time, the formal land laws provide no help for the problems with rented and mortgaged fields in the territory of the Ouldeme and Paltha.

Also, it is very difficult to receive a legal land title by the state due to massive transaction costs. To get a land title registered, a Ouldeme or Platha peasant would have to pay three or four times what he earns in a year and what he has paid to the owner for the field. The transaction costs include the following costs. First, one has to get to the information of how to apply for a legal title in a far away office. Second, one has to feed and pay a crew of state officials for the measurement of the field. Thirdly, the registration of the land title itself is costly and may possibly include a bribe for getting finally the legal title. It is no surprise that very seldom any Ouldeme or Platha applies for an official land title (Haller T., 1999, 2000, 2001).

Conclusions

This example from a peasant society in Africa shows how some so called "informal" traditional institutions governing the use of natural resources stay in place, although altered and transformed. They are adapted to the local changes in relative prices by the more powerful in order to have access to cash. On the other hand, those traditional institutions, which do not enable the gaining of cash are erased. They are no longer able to play their beneficial former role of reducing transaction costs and leading to sustainable use of natural resources. At the other hand those institutions that do survive, often in a transformed version, lower the transaction costs in order to have access to cash : They include norms and values of obligations that can be used easily in order to be extended in a monetary form. If a pride price is not paid, it is relatively easy to get the daughter back at the fathers home pushing the future husband and his group to co-operate. This is due to the fact that larger groups of people are profiting of a bride price (not only fathers but as well brothers, uncles and mothers) and so more pressure is laid on the proper price paid. On the other hand it is much more difficult to control the sons, who are now able to move freely and cannot be controlled in the same way anymore. The calculation of opportunity costs is for example for the head of a household that it is better to pay for a high bride price (with the institutional backing and the backing of the local kin group in order to monitor and sanction it) than to use his authority and keep the sorghum stored for hungry times. If he does not manage to do this, his sons will leave him and the terraces will be neglected. One option is therefore to rent an additional field for one year -where the terraces are not repairedor to give one's mortgaged field rented to a peasant repairing the terraces well to someone paying more, with the same consequence of lack of terrace-repair. The rules of maintenance and as well the rule of selling a field to a peasant of one's mountain section is no longer an option seeing the high cash which can be gained in short term by abolishing the old institutional land tenure system. For the women it seems to be the only option to produce beer for cash and no longer stick to the rule that beer shall 
only be produced for rituals, marriages and co-operation work. Women realise that firewood is getting scarce and more expensive and that the former wooden savannah in the plains and the adjacent mountain areas is logged to intensively but in the numerous discussions I had with commercial beer producing women they could not see any alternative.

At the same time formal institutions regarding land rights are not operating properly and are as well obstacles to better solutions. They in fact rise the transaction cost instead of lowering them for it is so costly to get a land title and therefore to be rewarded for an sustainable investment in soil and field improvement.

This shall underline the main hypothesis which should of course be tested by the study of a wider research setting. This is something I am trying to do in the future with a research project concerning five African floodplain wetlands in Zambia, Botswana, Cameroon, Mali and Tanzania but this time focusing more on the institutions for the management of common property resources (fisheries, wildlife, pasture and water). Eight researchers including myself are in the next four years working in these areas with the same research design developed by myself (see Haller T., 2001b, 2002b) ${ }^{6}$. The transformation of traditional institutions as well as the eradication of institutions that are unable to adapt to the monetarized world could provide a research topic for the future also in other areas. One of the aims should be to investigate transformed institutions, both new and old. It should be the aim to highlight the problems and possibilities for local participation in the sustainable use of natural resources and the discussion of how traditional institutions could be incorporated in order to be helpful governing and managing natural resources in Africa. To my view the New Institutionalism challenges naive views of traditional indigenous institutions and gives insights in how to analyse these rules of the game.

21 Of course, the idea that local indigenous institutions, which were helpful once, could be again incorporated or revitalised for governance purposes must be carefully studied. of major importance is getting the information of what often not homogenous actors of a local group are striving for (not only gender and age related categories but as well differences inside these groups as well as kinship, ethnical, political and economical differences). In order to profit from the gains of old institutions, transaction costs should be lowered and bargaining power has to be levelled by actors from development projects who are looking for the sustainable use of natural resources in participation. This is however not an easy task and perhaps not wanted by some of the local actors as well. Nevertheless, I think that a major step forward lies in the recognition of local resource rights and a fine tuned support of local user groups securing their resource base and starting to organise in order to solve problems. Much can be gained if we rise the awareness among developers for those processes and encourage them to discuss at length past and future institutions to govern environmental problems with a local population. 


\section{BIBLIOGRAPHIE}

Acheson J., 1989, “Management of Common-Property Resources”, in : Economic Anthropology. St. Plattner, (ed.). Standford : Standford Uni-Press. pp. 351-378.

Bayart J-F., 1993, The State in Africa. The Politics of the Belly. New York/london : Longman

Becker D.C., Ostrom E., 1995, "Human Ecology and Resource Sustainability: The Importance of Institutional Diversity". Annu. Rev. Ecol. Syst. n²6:113-33.

Berry S., 1989, “Social institutions and access to resources". Africa 59 (1): 41-55.

Berry S., 1993, No condition is permanent. The Social Dynamics of Agrarian Change in Sub-Saharan Africa. University of Wisconsin Press. Wisconsin.

Boserup E., 1965, The Condition of Agricultural Growth: The Economics of Agrarian Change under Population Pressure. Chicago : Aldine.

Chabal P., Daloz J-P., 1999, Africa Works : Disorder as Political Instrument. Indiana : James Curry.

Daget J., 1956, “La pêche à Diafarabé”. Etude monographique. Bulletin de l'IFAN (Institut français d'Afrique Noire), T. XVIII, Série B, $\mathrm{n}^{\circ}$. 1-2.

Davidson B., 1992, The Black Man's Burden. Africa and the Curse of the Nation-State. New York : Times Books.

Elwert G., 1985, "Märkte, Käuflichkeit und Moralökonomie”, in : Burkart, L., ed. Soziologie und gesellschaftliche Entwicklung. (Ohne Ort.)

Elwert G., 1989, “Nationalismus, Ethnizität und Nativismus - Über Wir-Gruppenprozesse”, in Waldman P. und. Elwert G. eds. Ethnizität im Wandel. Reihe Spectrum Nr. 21. Saarbrücken : Breitenbach Verlag.

Ensminger J., 1992, Making a Market. The Institutional Transformation of an African Society. Cambridge : Cambridge University Press.

Ensminger J., 1997, “Changing Property Rights : Reconciling Formal and Informal Rights to Land in Africa”, in John N. Drobak and John V.C. Nye (eds.) The Frontiers of the New Institutional Economics. New York : Academic Press. pp.165-198.

Ensminger J., 1998, “Anthropology and the New Institutionalism”. Journal of Institutional and Theoretical Economics (JITE), Vol. 154 :774-789.

Fay C.,1994, "Organisation sociale et culturelle de la production de pêche : morphologie et grandes mutations". In J. Quensière (Hrsg), La pêche dans le Delta Central du Niger, Paris :IER / ORSTOM/Karthala. pp.191-207.

Fay C., 2000, "Des poissons et des hommes: pêcheurs, chercheurs et administrateurs face à la pêche au Maasina (Mali)". In J.-P. Chauveau et al. (Hrsg), Les pêches piroguières en Afrique de l'Ouest. Paris : CMI, IRD, Karthala. pp. 125-166.

Gibson C., C., 1999, Politicians and Poachers. The Political Economy of Wildlife Policy in Africa. Cambridge, Cambridge University Press.

Haller T., 1995, "Raub der "Seelenschatten" in Nord-Kamerun. Krankheit bei den Ouldeme und Platha in den Mandarabergen". In Keller, Frank-Beat (Hg.). Krank warum? Vorstellung der Völker, Heiler und Mediziner, Katalog zur gleichnamigen Ausstellung. Ostfildern : Cantz Verlag. pp.302-306. 
Haller T., 1999, "Migration, Bierproduktion und Umweltkrise: Anpassungsstrategien an die monetäre Umwelt in den Mandarabergen Nord-Kameruns", in : L. Roost-Vischer, A. Mayor, D. Henrichsen (Hgs.), Brücken und Grenzen/Passage et frontières (Le forum suisse des africanistes 2), Münster: Lit-Verlag, 116-135.

Haller T., 2000, "Bodendegradierung und Ernährungskrise bei den Ouldeme und Platha. Umweltund Ernährungsprobleme bei zwei Feldbauerngruppen in den Mandarabergen Nord-Kameruns : Eine Folge der Adaptation an Monetarisierung und Wandel traditioneller institutioneller Rahmenbedingungen", in : Zeitschrift für Ethnologie 124 (1999) : 335-354.

Haller T., 2000, "Common Property Resource Management, Institutional Change and Conflicts in African Floodplain Wetlands : Presentation of a research project and reflections on institutional change and conflicts". The African Anthropologist, Vol. 9, n¹, March 2002 25-35.

Haller T., 2001, "Leere SPEICHER, erodierte Felder und das Bier der Frauen. Umweltanpassung und Krise bei den Ouldeme und Platha in den Mandarabergen Nord-Kameruns", Studien zur Sozialanthropologie. Berlin : Reimer Verlag.

Haller T., 2001b, Common Property-Institutionen und Machtbeziehungen : Ressourcenmanagement, Wandel und Konflikte in Feuchtgebieten Afrikas. Eingabe beim Schweizerischen Nationalfonds.

Haller T., 2002, Common Property Resource Management, Institutional Change and Conflicts in African Floodplain Wetlands: Presentation of a research project and reflections on institutional change and conflicts. $11^{\text {th }}$ Annual Conference of the Pan African Anthropological Association at the University Omar Bongo, Libreville, Gabon 20.-23/8/2001, African Anthropologist Vol I, 2002.

Hardin, G., 1968, "The Tragedy of the Commons." Science 162 : 1243-48.

Little P., D., 1985, “Absentee Herd Owners and Part-Time Pastoralists : The Political Economy of Resource Use in Northern Kenya". Human Ecology 13(2) :131-151.

Lund, C., 1998, "Law, Land and Politics in Niger": Land struggles and the rural Code. Hamburg :Lit Verlag.

Moorehead R., 1989, "Changes Taking Place in Common-Property Resource Management in the Inland Niger Delta of Mali" in F. Berkes. Hg., Common Property Resources. London: Belhaven Press. pp.256-272.

North, D., 1990, Institutions, Institutional Change and Economic Performance. Cambridge : Cambridge University Press.

Ostrom E., 1990, Governing the Commons. The Evolution of Institutions for Collective Action. Cambridge : Cambridge University Press.

\section{NOTES}

1. APAD-ASC-Conference in Leiden, The Netherlands May 22-25, 2002

2. In my original paper with the title "Indigenous institutions and sustainable resource use: Challenges and insights from the perspective of the New Institutionalism" presented at the conference I did discuss two further examples as well (pastoralists in Kenya (Little P., 1985) and fishers in Mali (Fay C., 1994, 2000)). In these cases similar changes in institutions can be observed. However for the sake of the uniformity of this APAD Bulletin, the editors asked me to rewrite the paper and focus on my own fieldwork material on the Ouldeme and Platha (1990-1991). 
3. Of course this dichotomy is based on an economic view. A closer look from legal anthropology would suggest that one can find some informality in the handling of formal state institutions, while locally developed rules for example for succession can be very formalised although not written down. However in this discussion, where the state is an important factor I regard the dichotomy as helpful, for on the state level mostly the written form is the relevant one if the state can govern effectfully.

4. Hardin states that resources held in common have to be overused because they belong to nobody and nobody takes care of them.

5. All data on the Ouldme and Platha can be found im my PhD-publication (Haller T., 2001) and several articles (Haller T., 1995, 1999, 2000, 2002)

6. Three African PhD students are integrated in a Swiss research program called "National Centre of Competence in Research (NCCR) North South : Research Partnerships for Mitigating Syndromes of Global Change". (Underproject IP 6: Institutional Change and Livelihood Strategies). The NCCR North South is lead by the Centre for Development and Environment, Department of Geography, University Berne, Switzerland and financed by the Swiss National Science Foundation (SNSF) and the Swiss Agency for Development and Cooperation (SDC). My own post-doc research is done in Zambia and is financed by the SNSF. Two MA-students are doing research in Mali and are financed partly by the Department of Social Anthropology, University of Zurich and by themselves. There is one MA-student working in Botswana (co-financed by the Anthropology Department,Zurich and by himself) and one MA-student working in Northern Cameroon (financed by NCCR, Anthropology Department and by herself).

\section{AUTEUR}

TOBIAS HALLER

Department of Social Anthropology, University of Zurich, Switzerland 